\title{
Photosynthetic Compensation to Partial Leaf Area Reduction in Sour Cherry
}

\author{
Desmond R. Layne ${ }^{1}$ and J.A. Flore ${ }^{2}$ \\ Department of Horticulture, Michigan State University, East Lansing MI 48824-1325
}

\begin{abstract}
Additional index words. Prunus cerusus, $\mathrm{CO}_{2}$ compensation point, carbonation efficiency, internal $\mathrm{CO}_{2}$ concentration, stomatal conductance, stomatal limitations, dark respiration, light compensation point, photochemical efficiency, photorespiration, rubisco, RuBP, wound ethylene, specific leaf density
\end{abstract}

\begin{abstract}
The leaf surface area of l-year-old, potted 'Montmorency' sour cherry (Prunus cerasus L.) trees was reduced by punching disks from some or all leaves to determine the threshold level of leaf area removal (LAR) necessary to reduce net $\mathrm{CO}_{2}$ assimilation (A) and whole-plant growth. Removal of $30 \%$ of the leaf area of individual leaves reduced $A$ on a whole-leaf basis between 1 and 3 weeks following LAR. Less than 30\% LAR was compensated for by higher estimated carboxylation efficiency and ribulose-1,5-bisphosphate (RuBP) regeneration capacity. The threshold level of LAR based on gas exchange of individual leaves was $20 \%$. Although whole-plant dry weight accumulation was reduced at all levels of LAR, a disproportionately large decrease in dry weight occurred as LAR increased from $20 \%$ to $30 \%$. This result indicates that $30 \%$ LAR exceeded the threshold LAR level that was noted for A $(20 \%$ LAR). Wound ethylene production induced by leaf-punching ceased after 24 hours, which indicated that wounds had healed and that ethylene, therefore, did not influence A significantly. The observed threshoId of $20 \%$ LAR represents a significant compensation ability for sour cherry, but this threshold may change with crop load, environment, or both.
\end{abstract}

Sour cherry foliage injury may result from various biotic and abiotic factors. Some of these include: mite or insect feeding; invasion by fungi, bacteria, or viruses; pesticide phytotoxicity; wind or hail damage; and air pollution. As a result of injury, parts of individual leaves may become photosynthetically nonfunctional. The extent and timing of injury may reduce the carbon assimilation potential of the tree.

The response of apple (Malus domestics Borkh.) trees to insect and disease infestation has been documented extensively. Infestations by mites reduced apple yield and trunk growth (Lienk et al., 1956), shoot extension and tissue dry weights (Briggs and Avery, 1968), and A and transpiration rates (Mobley and Marini, 1990). Childers et al. (1941) and Proctor et al. (1982) reported reductions in A following infestations with leafhoppers (Typhlocyba pomaria McAtree) and tentiform leaf miner (Phyllonorycter blancardella Fabricius), respectively. Assimilation rates of apple leaves were also reduced following infection with apple scab [Venturia inaequalis (Cke.) Wint.] (Spotts and Ferree, 1979) or powdery mildew (Podosphaera leucotricha Salm.) (Ellis et al., 1981).

Several methods of artificial defoliation have been used to simulate pest damage and establish crop damage-yield relationships on various crops. Poston et al. (1976) noted that reducing leaf area with a cork borer adequately simulated painted lady caterpillar (Cynthiana cardui L.) and green clover-worm (Plathypena scabra F.) defoliation of soybean (Glycine max L.). LAR using a cork borer or paper hole-punch (Boucher et al., 1987; Flore and Irwin, 1983), leaf injury by cutting the midrib or pricking the lamina ( $\mathrm{Li}$ and Proctor, 1984), and leaf removal (Stacey, 1983) have all been used to simulate pest damage.

Many plants are capable of compensating for some level of leaf injury or LAR by increasing their photosynthetic rate. Pho-

\footnotetext{
Received for Duplication 1 Julv 1991. Accepted for publication 12 Nov. 1991. We acknowledge the Michigan Agricultural Experiment Station for their support of this research. This research was supported in part by USDA grant no. 8834132-3380. The cost of publishing this paper was defrayed in part by the payment of page charges. Under postal regulations, this paper therefore must be hereby marked advertisement solely to indicate this fact.

'Graduate Research Assistant.

${ }^{2}$ Professor.
}

tosynthetic compensation has been observed in diverse crops (Boucher et al., 1987; Flore and Irwin, 1983; Hodgkinson, 1974; Poston et al., 1976; Proctor et al., 1982; Satoh et al., 1977; Shaw and Samborski, 1956; von Caemmerer and Farquhar, 1984; Wareing et al., 1968). Whole-plant defoliation up to $20 \%$ in apple (Flore and Irwin, 1983), 25\% in tomato (Lycopersicon esculentum Mill.) (Stacey, 1983), and 40\% in various hybrid poplar clones (Populus sp. L.) (Bassman et al., 1982) were compensated for, as indicated by no decrease in dry weight accumulation, fruit yield, and vegetative growth, respectively.

The objectives of this study were to: 1) determine what the threshold LAR level is for leaf A in sour cherry; 2) characterize the physiological effect of LAR by determining the change in A to a range of physiologically significant $\mathrm{CO}_{2}$, light, and $\mathrm{O}_{2}$ levels; 3 ) determine if the LAR threshold based on gas exchange of individual leaves corresponds to the threshold observed for growth of whole plants; and 4) document the wound response to LAR by leaf-punching.

\section{Materials and Methods}

Dormant 1-year-old sour cherry trees ('Montmorency' on Mahaleb rootstock) were planted in n-liter plastic pots with 9.5 liters of sterilized greenhouse soil mix [5 sandy loam :3 sphagnum peat $: 2$ torpedo sand (by volume), $\mathrm{pH}=7.0]$. All trees were cut back to an active bud (0 to $10 \mathrm{~cm}$ above the graft union) and placed in an environmentally controlled greenhouse (day and night means 24 and $18 \mathrm{C}$, respectively, 16-h photoperiod provided with high-pressure sodium lamps). Trees were trained to a single shoot from which all laterals were removed as they appeared. Peter's soluble 20N-20P-20K fertilizer (500 ppm) was applied every 3 weeks, and trees were watered every 3 days. Pesticides [5-O-demethylavermectin/(abamectin, Avid), cyano(4-fluoro-3-phenoxyhenyl)methyl-3(2,2-dichloroethenyl)-2,2-dimethylcyclopropanecarboxylate (cyfluthrin, De-

\footnotetext{
Abbreviations: $\mathrm{A}$, net $\mathrm{CO}$, assimilation; $\mathrm{A}_{\max }$, maximum net $\mathrm{CO}_{2}$ assimilation; $\mathrm{C}_{\mathrm{i}}$, internal $\mathrm{CO}_{2}$ concentration; $\mathrm{K}$, carboxylation efficiency LA, leaf area; LAR, leaf area removal; PPF, photosynthetic photon flux; $\mathrm{R}_{1}$, photorespiration; RuBP, ribulose-1,5-bisphosphate; SLD, specific leaf density TCA, trunk crosssectional area; to, photochemical efficiency or quantum yield.
} 
cathlon), and d-(2-chlorophenyl)-d-(4-chlorophenyl)-5-pyrimidine-methanol (fenarimol, Rubigan)] were applied as necessary.

Statistical design. For all experiments, plants were arranged in a split plot, with position of LAR (between or across lateral veins) as the main plot randomized completely within the plant population; half of the plants had LAR across veins and the other half had LAR between veins. The subplot (LAR levels) were completely randomized on each plant.

Gas exchange experiments. Forty of the most uniform plants were selected based on leaf count, total leaf area, and gas exchange characteristics after 2 months of growth in the greenhouse (20 fully expanded leaves per plant, on average). The four most recently fully expanded leaves on each plant were tagged and leaf area (LA) was determined according to Kappes (1985), where LA $=($ length $\times$ width $\times 0.671)$. Each of the tagged leaves was randomly assigned a different LAR treatment corresponding to 0 (control), $10 \%, 20 \%$, or $30 \%$ of the total LA. LA was removed at about the same time using a paper punch $\left(\right.$ area $\left.=0.33 \mathrm{~cm}^{2}\right)$. The leaf margin and midrib were not disturbed on any leaf. There were 20 replicate plants for each of the across or between-vein LAR treatments.

Dry weight experiment. A second population of similar plants was grown under identical conditions. The most uniform 64 plants (based on fresh weight at planting) were selected and treatments were randomly assigned. Whole-plant LA was reduced 0 (control), $10 \%, 20 \%$, or $30 \%$ as described above, where half of the plants had LAR across veins and half between veins. LA was reduced weekly on the most recently expanded leaves of each plant until terminal bud set. The experiment was terminated after 20 weeks of growth in the greenhouse, and the following data were collected for each plant (eight replicates per treatment): plant height from the base of the shoot to the terminal bud; total leaf count; actual LA (LA - area removed by punching); trunk cross-sectional area (TCA) at the base of the shoot; and, following 14 days in a forced-air dryer (40C), dry weights of leaves, scion wood, and rootstock. The average specific leaf density (SLD) per plant was determined as the total leaf dry weight per unit of actual area divided by the number of leaves.

Wound ethylene experiment. A third population of plants grown under identical conditions to that described above was selected to evaluate the wounding response (by ethylene production) following LAR. Four replicate plants were used for each treatment and four leaves were measured for each plant. Conditions were identical to those described for the gas exchange experiment, except that tagged leaves were excised at the time of measurement (wound ethylene protocol follows).

Gas exchange measurements. Gas exchange was measured in the laboratory using the open gas exchange system described by Sams and Flore (1982) and modified as follows: a) an ADC 225 MK3 infrared gas analyzer (Analytical Development Co., Hoddesdon, U. K.) was used to measure differential $\mathrm{CO}_{2}$ concentrations at the inlet and outlet of the leaf chambers; and $b$ ) air flow entering the chambers was regulated using the following Matheson equipment (Matheson Instruments, Horsham, Pa.): 8100 series flow meters and 8200 series mass flow controllers connected to a model 8219 multichannel Dyna-Blender. Ambient $\mathrm{CO}_{2}$ concentrations were measured using a portable ADC LCA2 infrared gas analyzer, and $\mathrm{O}_{2}$ concentration was determined with a 0-260 Beckman $\mathrm{O}_{2}$ analyzer (Beckman Instruments, Irvine, Calif.). Trees and assimilation chambers were placed in a Conviron PGV36 walk-in plant growth chamber (Conviron Systems of America, Pembina, N.D.), and temper- ature, relative humidity, and light intensity around the whole plant were adjusted to coincide with the assimilation chamber conditions.

The effect of LAR on A over time was determined in the following manner. At predetermined intervals $(0,1,4,7,14$, 21 , and 28 days following LAR), five plants each for both positions of injury were selected from the population of 40 plants and brought to the laboratory. Plants were allowed to acclimate for $90 \mathrm{~min}$ in the growth chamber [25C, 50\% relative humidity, $800 \mu \mathrm{mol} \cdot \mathrm{m}^{-2} \cdot \mathrm{s}^{-1}$ photosynthetic photon flux (PPF)]. Four leaf chambers were used simultaneously in which the following conditions were maintained, unless otherwise indicated: inlet $\mathrm{CO}_{2}$ and $\mathrm{O}_{2}, 350 \pm 15 \mu \mathrm{l} \cdot$ liter $^{-1}$ and $21 \mathrm{kPa}$, respectively; leaf temperature, $25 \mathrm{C}$; vapor pressure deficit (VPD), $1.0 \pm 0.2 \mathrm{kPa}$; inlet flow rate, 3 liters $\cdot \mathrm{min}^{-1}$. Measurements were conducted between 9:00 AM and 12:00 noon (to minimize the diurnal effect). On a given day of measurement, A for an individual leaf was expressed as a percentage of the observed A on day 0 for that same leaf; this value was then expressed as a percentage of the A of the control leaf on the same plant for the same day of measurement.

Response to changing environmental conditions. Response to PPF was determined on days 11 and 12 following LAR, as described above, by decreasing PPF stepwise (15-min acclimation at each step) to the following levels: 1800, 1300, 1000, $600,400,180$, and $0 \mu \mathrm{mol} \cdot \mathrm{m}^{-2} \cdot \mathrm{s}^{-1}$ Photosynthetically active radiation (PAR) was provided with GE 400-W metal halide lamps. These PPF levels were produced using a combination of neutral density filters. PAR was measured with a LI-COR 190 PAR sensor (LI-COR, Lincoln, Neb.). Dark respiration $\left(\mathrm{R}_{\mathrm{d}}\right)$ was measured by gas exchange after $20 \mathrm{~min}$ in complete darkness.

Photorespiration $\left(\mathrm{R}_{1}\right)$ was estimated on day 13 by comparing $\mathrm{A}$ at ambient $\mathrm{O}_{2}(21 \mathrm{kPa})$ with that at reduced $\mathrm{O}_{2}(1.5 \mathrm{kPa})$. Response to $\mathrm{CO}_{2}$ was determined on days 15 to 17 following LAR by increasing stepwise to the following levels: $0,60,115$, 175, 240, 300, 350, 430, 520, and $900 \mu \mathrm{l} \cdot$ liter $^{-1}$. Leaves were allowed to acclimate for $20 \mathrm{~min}$ at each $\mathrm{CO}_{2}$ level.

Gas exchange parameters were calculated using the BASIC computer program of Moon and Flore (1986). Responses of A to PPF and internal $\mathrm{CO}_{2}$ concentration $\left(\mathrm{C}_{\mathrm{i}}\right)$ were analyzed for each treatment by nonlinear regression, and curve fitting was performed using the Marquardt compromise method of successive approximations. The best-fit curve, evaluated by analysis of residuals, and $r^{2}$ were the monomolecular asymptotic function (Hunt, 1980) of the type: $\mathrm{Y}=\mathrm{B}(1) \times\left[1.0-\mathrm{B}(2) \mathrm{e}^{-\mathrm{B}(3) \times \mathrm{x}}\right]$, where $\mathrm{B}(1), \mathrm{B}(2)$, and $\mathrm{B}(3)$ are the asymptotic value, minimum value, and rate constant, respectively. This polynomial was selected because it provided direct estimates of specific physiological processes and exhibited curvilinear features that represented the data. Individual leaf A vs. $\mathrm{C}_{\mathrm{i}}$ and $\mathrm{A}$ vs. PPF response curves were developed using this polynomial.

Carbon dioxide compensation point $(\Gamma)$ was extrapolated from the $\mathrm{AC}_{\mathrm{i}}$ curve as the $\mathrm{C}_{\mathrm{i}}$ at which $\mathrm{A}$ was zero. Carboxylation efficiency (k) was calculated from the raw data as the slope in the linear portion of the $\mathrm{AC}_{\mathrm{i}}$ curve. Stomatal limitation $\left(\mathrm{l}_{\mathrm{g}}\right)$ was calculated according to the differential method of Jones (1985). Photochemical efficiency or quantum yield $(\phi)$ was calculated from the raw data as the slope of the A vs. PPF curve in the linear portion between 0 and $180 \mu \mathrm{mol} \cdot \mathrm{m}^{-2} \cdot \mathrm{s}^{-1} \mathrm{PPF}$. The light compensation point (cp) was extrapolated from the light response curve as the PPF level at which A was zero. $R_{d}$ was calculated from the raw data at $0 \mu \mathrm{mol} \cdot \mathrm{m}^{-2} \cdot \mathrm{s}^{-1} \mathrm{PPF}$. 
Wound ethylene measurement. Ethylene evolution was determined according to the method of Lownds (1987) and modified as follows: leaves were excised immediately after LAR, positioned abaxial side outward with minimum overlap in $25 \times$ 200-mm test tubes, and with the petiole immersed in $2 \mathrm{ml}$ of distilled water. Tubes were immediately sealed with rubber serum stoppers, incubated in a constant-temperature water bath (25C), and illuminated with fluorescent lights at $115 \mu \mathrm{mol} \cdot \mathrm{m}^{-2} \mathrm{~s}^{-1} \mathrm{PPF}$. The ethylene concentration in the tubes was determined from a 1-ml headspace sample by gas chromatography (Varian 1440; Varian Associates, Palo Alto, Calif.) using a flame ionization detector. The injection port, column, and detector temperatures were 130,100 , and $150 \mathrm{C}$, respectively. Nitrogen $\left(\mathrm{N}_{\mathrm{z}}\right)$ flow was maintained at $15 \mathrm{ml} \cdot \mathrm{min}^{-1}$. Ethylene was sampled hourly for the first $12 \mathrm{~h}$ following LAR and again at 24, 48, and $72 \mathrm{~h}$. Tubes were flushed with ethylene-free air for $30 \mathrm{sec}$ and then resealed following each determination. The rate of ethylene evolution was expressed in units of nanoliters per gram of leaf fresh weight per hour.

\section{Results}

Gas exchange over time. LAR reduced A within 1 day when more than $10 \%$ of the LA was removed between lateral veins (Fig. 1A) or when as little as $10 \%$ was removed across veins (Fig. 1B). Recovery occurred within 4 days when no more than $20 \%$ of the LA was removed. Two weeks following treatment, the rates of $\mathrm{A}$ were $12 \%$ and $66 \%$ above the control value in leaves with $20 \%$ LAR between and across veins, respectively. The greatest increase in A was observed for leaves 2 weeks following LAR across veins and 3 weeks following LAR between veins. The time to full photosynthetic recovery was slowest when $30 \%$ of the LA was removed.

Since enhancement of A was observed between days 7 and

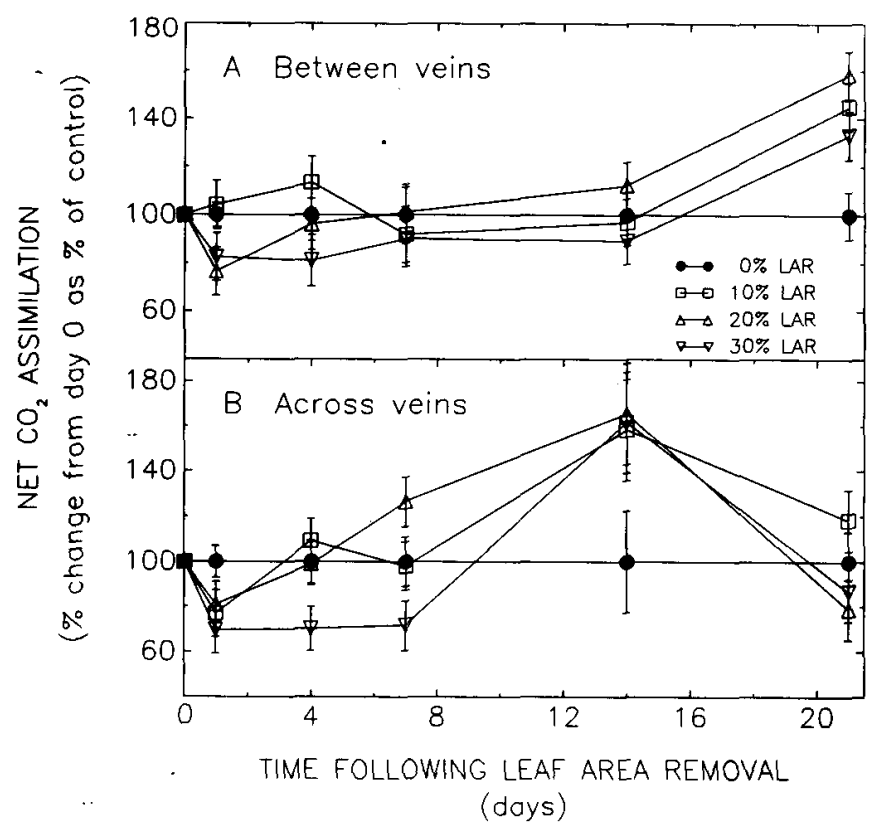

Fig. 1. Changes in A (actual LA basis) over time of sour cherry leaves as affected by removal of $0 \%(\bullet), 10 \%(\square), 20 \%(\triangle)$, or $30 \%(\nabla)$ of the leaf area either between (A) or across (B) lateral veins by leaf-punching. The A value is expressed as the percent change from the pretreatment value (day-0) for a particular leaf relative to the nondefoliated leaf on the same plant for the date of measurement indicated. Means $\pm S E(n=4)$.
21 following LAR (Fig. 1 A and B), the gas exchange data for these dates were combined for each treatment to describe the effect of increasing levels of LAR on A (Fig. 2). When data were expressed based on the actual LA remaining following LAR (Fig. 2A), the quadratic relationships between A and LAR between and across veins were nonsignificant $\left(r^{2}=0.05\right)$ and significant $\left(r^{2}=0.15\right)$, respectively. When data were expressed based on the original LA before LAR (Fig. 2B), the quadratic relationship between A and LAR was significant for both methods of LAR $\left(r^{2}=0.18\right.$ and 0.36 , respectively). Comparison of SE based on actual or original leaf area (Fig. 2) demonstrated that only $30 \%$ LAR across veins reduced A relative to the control.

Gas exchange response to $\mathrm{CO}_{2}$ level. The data fit the model equation used to predict the response of $\mathrm{A}$ to $\mathrm{C}_{\mathrm{i}}$ very well $\left(r^{2}=\right.$ 0.96). The $\mathrm{AC}_{\mathrm{i}}$ curves presented (Fig. 3) are based on the combined data for the four replicate leaves for a-given treatment. As $\mathrm{C}_{\mathrm{i}}$ increased, A increased hyperbolically for all treatments. A rates were higher in leaves with $10 \%$ or $20 \%$ LAR between veins than in the control at most $\mathrm{CO}_{2}$ levels above $115 \mu \mathrm{l} \cdot$ liter $^{-1}$ (Fig. $3 \mathrm{~A}$ and $\mathrm{C}$, respectively), but not in leaves with $30 \%$ LAR between veins (Fig. 3E). LAR across veins reduced A relative to control leaves at $\mathrm{CO}_{2}$ levels at or exceeding $175 \mu \mathrm{l} \cdot \operatorname{liter}^{-1}$ (Fig. $3 \mathrm{~B}, \mathrm{D}$, and F).

Based on the A vs. $\mathrm{C}_{\mathrm{i}}$ analysis of individual leaves, the treatment effects on various characteristics were calculated (Table 1). $\Gamma$ was not significantly affected by LAR position, but it was affected by LAR level. $\mathrm{k}$ was significantly affected by position and level of LAR, and there was a significant interaction between position and level of LAR. LAR increased $\mathrm{k}$ values $83 \%$ and $72 \%$ when $10 \%$ and $20 \%$ of the LA was removed between veins, respectively. LAR resulted in $\mathrm{k}$ values that were $33 \%$ and $29 \%$ lower than for control leaves when $10 \%$ or $30 \%$ of the LA was removed across veins, respectively. A at ambient $\mathrm{CO}_{2}\left(\mathrm{~A}_{350}\right)$ was significantly affected by LAR position, level, and the interaction thereof. $\mathrm{A}_{350}$ was reduced by LAR across

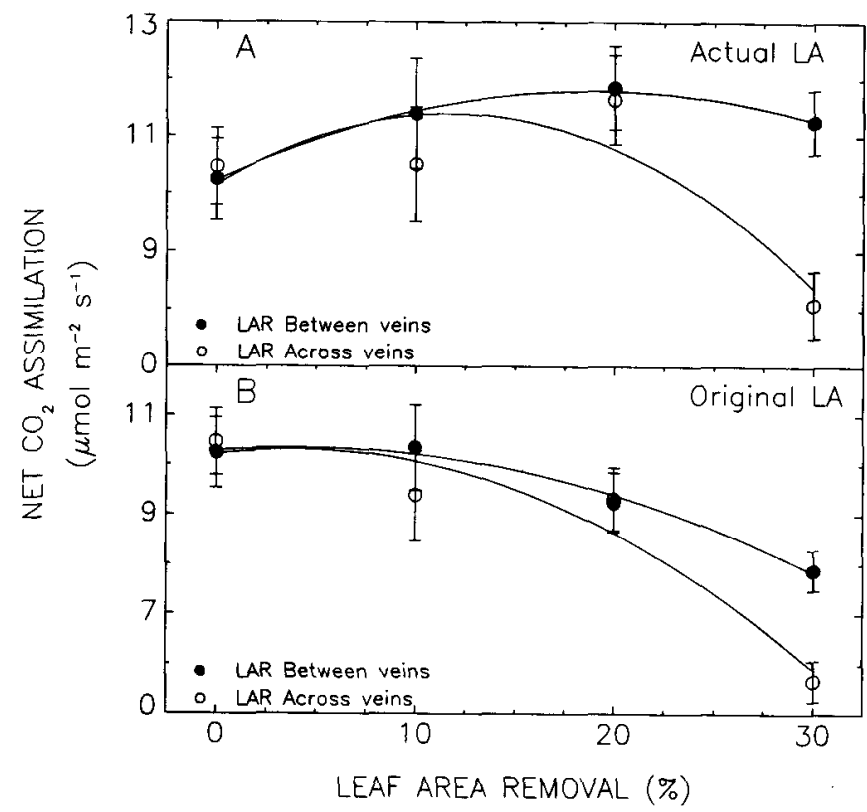

Fig. 2. Effect of LAR of sour cherry leaves by leaf-punching between (O) or across (O) lateral veins on the relationship between percent LAR and A. Data were expressed based on actual LA remaining following LAR (A) or on original LA before LAR (B). Means \pm SE $(\mathrm{n}=12)$. 


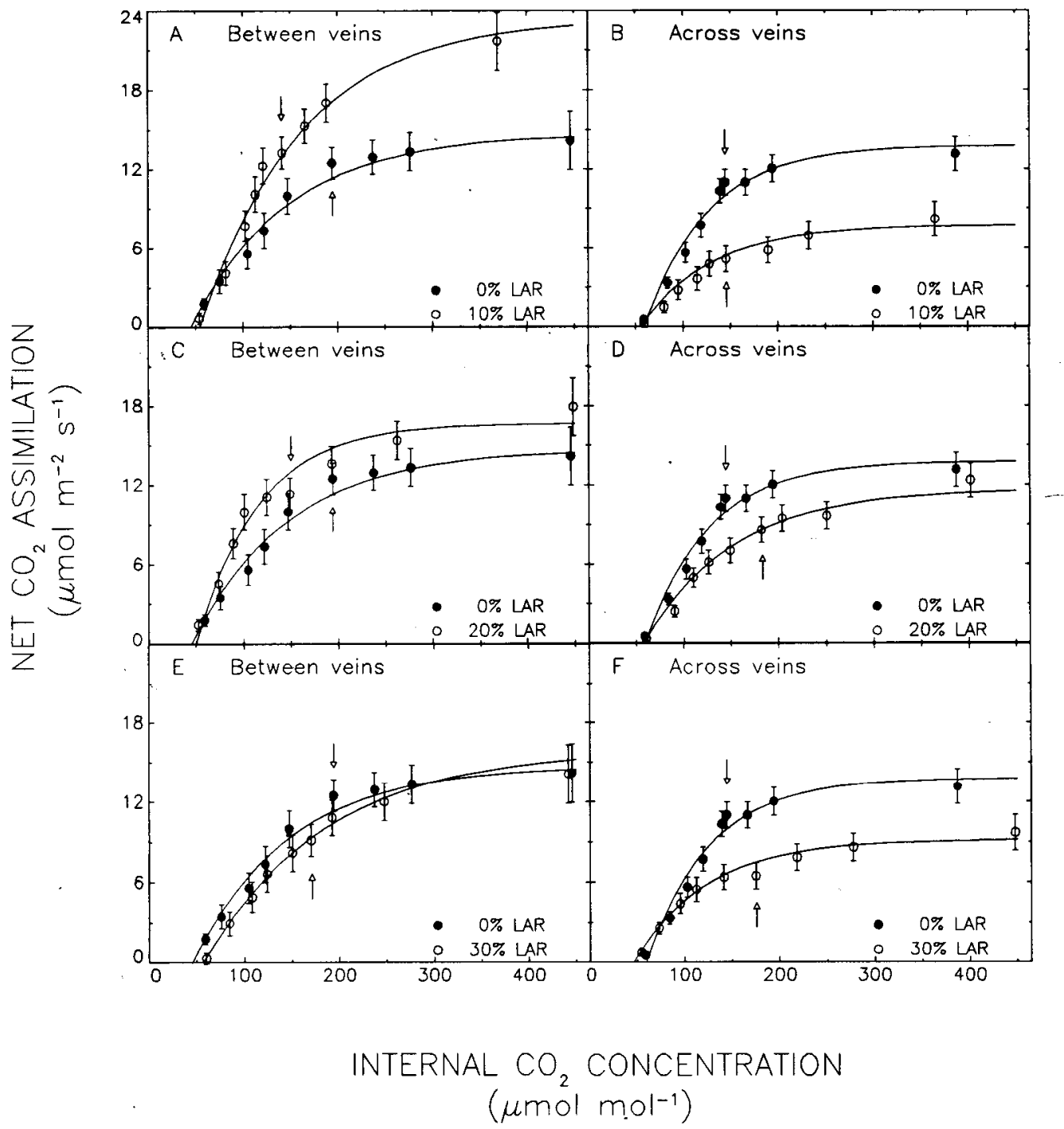

Fig. 3. Effect of LAR of sour.cherry leaves by leaf-punching between or across lateral veins on the relationship between $\mathrm{A}$ and internal $\mathrm{CO}_{2}$ concentration. Data for each treatment $(\mathrm{O})$ are presented relative to the noninjured control $(\mathbf{O})$ in each figure. (A, C, E) $10 \%, 20 \%$, and $30 \%$ between lateral vein LAR treatments, respectively; (B, D, F) $10 \%, 20 \%$, and $30 \%$ across lateral vein LAR treatments, respectively. Arrows correspond to measurements at ambient $\mathrm{CO}_{2}\left(350 \pm 20 \mu l \cdot l i t e r^{-1}\right)$. Means $\pm \mathrm{SE}(\mathrm{n}=4)$.

veins. $\mathrm{A}_{350}$ was significantly lower than the control when $10 \%$ or $30 \%$ of the LA was removed across lateral veins. Stomatal conductance at ambient $\mathrm{CO}_{2}\left(\mathrm{~g}_{8350}\right)$ was not affected by position of LAR. Across-vein LAR of $10 \%$ or $30 \%$ significantly reduced $\mathrm{g}_{\mathrm{s} 350}$ relative to the control. At $900 \mu \mathrm{l} \cdot \operatorname{liter}^{-1} \mathrm{CO}_{2}$, maximum A $\left(\mathrm{A}_{\max }\right)$ was significantly affected by position and level of LAR. $A_{\max }$ was higher than in controls by $53 \%$ and $27 \%$ at $10 \%$ or $20 \%$ LAR between veins, respectively. $\mathrm{A}_{\max }$ was reduced by $39 \%$ or $26 \%$ at $10 \%$ or $30 \%$ LAR across veins, respectively. $1_{\mathrm{g}}$ was minimally affected by LAR level.

Gas exchange response to PPF. The data fit the model equation used to predict the response of A to PPF very well $\left(r^{2}=\right.$ 0.94). As PPF increased, A increased hyperbolically for all treatments (response curves not shown). The treatment effects on various calculated values were determined based on the A vs. PPF analysis for individual leaves (Table 2). $\mathrm{R}_{\mathrm{d}}$ was not significantly affected by LAR position and minimally affected by LAR level. cp was lower when leaf area was removed between lateral veins. $\phi$ was significantly affected by LAR position and level. $\phi$ was reduced from control values by $40 \%$, $32 \%$, or $41 \%$ when $10 \%, 20 \%$, or $30 \%$ of the LA was removed across veins, respectively. Maximum A at $1300 \mu \mathrm{mol} \cdot \mathrm{m}^{-2} \cdot \mathrm{s}^{-1}$ TPF $\left(\mathrm{A}_{\max }\right)$ was significantly affected by LAR position and level. $A_{\max }$ was reduced by $26 \%, 31 \%, 27 \%$, or $35 \%$ when $30 \%$ LAR was removed between veins or $10 \%, 20 \%$, or $30 \%$ of the leaf area was removed across veins, respectively. $\mathrm{R}_{1}$ was significantly affected by LAR position and level. $\mathrm{R}_{1}$ was significantly increased by all LAR treatments.

Whole-plant growth. Weekly LAR significantly reduced height, leaf number, actual LA, TCA, and dry weight per plant whether lateral veins were cut or not (Table 3). Average SLD per plant increased significantly as LAR level increased. Only small differences in height, leaf number, TCA, or plant dry weight were noted between the $10 \%$ and $20 \%$ LAR treatments. However, $30 \%$ LAR resulted in disproportionately large reductions of these variables when compared to the $20 \%$ LAR treatment.

Wound ethylene evolution. Wound ethylene evolution from LAR treatments increased hourly to a peak rate after $4 \mathrm{~h}$ and then decreased to negligible levels $24 \mathrm{~h}$ following LAR (data not shown). At each LAR level, ethylene evolution was significantly higher when leaf area was removed across rather than between lateral veins. The highest and lowest rates of ethylene 
Table 1. The effect of LAR on $\mathrm{CO}_{2}$ compensation point $(\Gamma), \mathrm{k}$, net $\mathrm{CO}_{2}$ assimilation $\left(\mathrm{A}_{350}\right)$, and stomatal conductance $\left(\mathrm{g}_{\mathrm{s} 350}\right)$ at ambient $\mathrm{CO}_{2}, \mathrm{~A}_{\max }$ at $900 \mathrm{ppm} \mathrm{CO}_{2}$, and stomatal limitations to $\mathrm{A}\left(\mathrm{l}_{\mathrm{g}}\right)$ of expanded sour cherry leaves. ${ }^{z}$

\begin{tabular}{|c|c|c|c|c|c|c|}
\hline $\begin{array}{l}\text { LAR level } \\
(\%)\end{array}$ & $\stackrel{\Gamma}{\left(\mu \mathrm{mol} \stackrel{\Gamma}{\mathrm{C}} \mathrm{O}_{2} / \mathrm{mol}\right)}$ & $\begin{array}{c}\mathrm{k} \\
\left(\mathrm{mol} \mathrm{CO} \mathrm{C}_{2} / \mathrm{m}^{2}\right. \\
\text { per sec) }\end{array}$ & $\begin{array}{c}\mathrm{A}_{350} \\
\left(\mu \mathrm{mol} \mathrm{CO} / \mathrm{m}^{2}\right. \\
\text { per sec) }\end{array}$ & $\begin{array}{c}\mathrm{g}_{\mathrm{s}} 350 \\
\left(\mathrm{mmol} \mathrm{CO} / \mathrm{C}_{2}\right. \\
\text { per sec) }\end{array}$ & 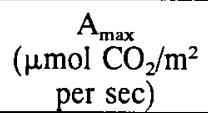 & $\begin{array}{l}\mathrm{l}_{\mathrm{g}} \\
(\%)\end{array}$ \\
\hline \multicolumn{7}{|c|}{ LAR between lateral veins } \\
\hline 0 & 54.0 & 0.099 & 12.48 & 48.3 & 14.18 & 41.7 \\
\hline 10 & 50.5 & 0.181 & 13.25 & 64.5 & 21.68 & 59.9 \\
\hline 20 & 52.5 & 0.170 & 11.33 & 49.7 & 17.94 & 32.4 \\
\hline 30 & 56.0 & 0.105 & 9.13 & 53.0 & 14.09 & 51.2 \\
\hline \multicolumn{7}{|c|}{ LAR across lateral veins } \\
\hline 0 & 63.0 & 0.103 & 10.92 & 83.7 & 13.14 & 34.5 \\
\hline 10 & 53.3 & 0.069 & 5.14 & 24.7 & 8.18 & 58.7 \\
\hline 20 & 57.5 & 0.111 & 8.60 & 53.7 & 12.34 & 41.8 \\
\hline 30 & 48.3 & 0.073 & 6.46 & 38.2 & 9.68 & 35.7 \\
\hline Position & NS & $* * *$ & $* * *$ & NS & $* * *$ & NS \\
\hline Level & $*$ & $* *$ & * & $*$ & $*$ & $*$ \\
\hline Position $\times$ level & NS & $* *$ & $* *$ & NS & NS & NS \\
\hline
\end{tabular}

${ }^{z}$ Values are the means of four replicates.

Ns,*,*****Nonsignificant or significant at $P=0.1,0.05$, or 0.01 , respectively. Position and level identify main and split-plot effects, respectively. Comparisons were made 15 to 17 days after LAR.

Table 2. The effect of LAR on dark respiration rate $\left(R_{d}\right)$, light compensation point (cp), $\phi, A_{\max }$ at $1300 \mu \mathrm{mol} \cdot \mathrm{m}^{-2} \cdot \mathrm{s}^{-1} \mathrm{PPF}$, and estimated $R_{1}$ of expanded sour cherry leaves. ${ }^{\mathrm{z}}$

\begin{tabular}{|c|c|c|c|c|c|}
\hline $\begin{array}{l}\text { LAR level } \\
(\%)\end{array}$ & $\begin{array}{c}\mathrm{R}_{\mathrm{d}} \\
\left(\mu \mathrm{mol} \mathrm{CO} / \mathrm{m}^{2}\right. \\
\text { per sec })\end{array}$ & $\begin{array}{c}\mathrm{cp} \\
\left(\mu \mathrm{mol} \mathrm{CO} / \mathrm{m}^{2}\right. \\
\text { per sec) }\end{array}$ & $\begin{array}{c}\phi \\
(\mu \mathrm{mol} \mathrm{CO} \text { fixed } / \\
\text { mol PPF) }\end{array}$ & $\begin{array}{c}\mathrm{A}_{\max } \\
\left(\mathrm{mmol} \mathrm{CO}_{2} / \mathrm{m}^{2}\right. \\
\text { per sec) }\end{array}$ & $\begin{array}{c}\mathrm{R}_{1} \\
(\%)\end{array}$ \\
\hline \multicolumn{6}{|c|}{ LAR between lateral veins } \\
\hline 0 & -0.51 & 13.5 & 0.0242 & 16.48 & 12.2 \\
\hline 10 & -0.57 & 16.3 & 0.0213 & 15.02 & 22.6 \\
\hline 20 & -0.79 & 18.3 & 0.0253 & 17.00 & 31.2 \\
\hline 30 & -0.60 & 13.2 & 0.0173 & 12.24 & 26.7 \\
\hline \multicolumn{6}{|c|}{ LAR across lateral veins } \\
\hline 0 & -0.73 & 13.7 & 0.0281 & 16.99 & 23.3 \\
\hline 10 & -0.62 & 19.5 & 0.0169 & 11.79 & 35.8 \\
\hline 20 & -0.76 & 22.8 & 0.0191 & 12.40 & 44.4 \\
\hline 30 & -0.68 & 27.3 & 0.0167 & 10.98 & 29.9 \\
\hline Position & NS & $*$ & $* *$ & $* * *$ & $* * *$ \\
\hline Level & $*$ & $*$ & **** & $* * *$ & $* * *$ \\
\hline Position $\times$ level & NS & NS & $*$ & NS & NS \\
\hline
\end{tabular}

${ }^{2}$ Values are the means of four replicates.

NS,*,**,***Nonsignificant or significant at $P=0.1,0.05$, or 0.01 , respectively. Position and level identify main and split-plot effects, respectively. Comparisons were made 11 to 13 days after LAR.

evolution $4 \mathrm{~h}$ following LAR were 99 and $33 \mathrm{nl} \cdot \mathrm{g}^{-1} \cdot \mathrm{h}^{-1}$, respectively, for the $20 \%$ LAR, including across- and betweenvein LAR treatments. After $24 \mathrm{~h}$, ethylene evolution had decreased in these same treatments to 4.7 and $2.5 \mathrm{nl} \cdot \mathrm{g}^{-1} \cdot \mathrm{h}^{-1}$, respectively, and were similar to those of the control.

\section{Discussion}

Many cultivated plants can compensate for partial defoliation by increasing the photosynthetic capacity of the remaining leaf area (Boucher et al., 1987; Flore and Irwin, 1983; Hodgkinson, 1974; Poston et al., 1976; Proctor et al., 1982; Satoh et al., 1977; Shaw and Samborski, 1956; von Caemmerer and Farquhar, 1984; Wareing et al., 1968). Similar physiological responses occur whether whole leaves or portions of individual leaves are removed. The initial reduction in A following LAR in sour cherry (Fig. 1) has also been observed following leaf area loss in grape (Vitis vinifera L.) (Boucher et al., 1987). Depending on the type and extent of defoliation, significant enhancements of A have been observed in as few as 2 to 3 days in bean (Phaseolus vulgaris L.) (von Caemmerer and Farquhar, 1984) or 6 days following decapitation of mulberry (Morus alba L.) (Satoh et al., 1977). In sour cherry, a significant enhancement of $\mathrm{A}$ in the remaining effective LA relative to a control leaf was not observed until 7 days following $20 \%$ LAR across lateral veins (Fig. 1B). This compensation response of an individual cherry leaf to LAR is slower than that of intact leaves remaining on partially defoliated cherry plants, in which compensation was noted after 1 day (Layne and Flore, 1991). Photosynthetic enhancement of up to $50 \%$ to $70 \%$ on an actual leaf area basis (Fig. 1) was observed 2 to 3 weeks following partial defoliation. In fact, von Caemmerer and Farquhar (1984) observed more than a doubling of A 2 weeks after partially defoliating bean plants. Between 1 and 3 weeks following LAR, 
Table 3. The effect of weekly LAR on plant height, leaf number, actual LA, TCA, dry weight, and average SLD of 1-year-old potted sour cherry trees. ${ }^{z}$

\begin{tabular}{|c|c|c|c|c|c|c|}
\hline $\begin{array}{l}\text { LAR level } \\
(\%)\end{array}$ & $\begin{array}{l}\text { Plant ht } \\
\text { (cm) }\end{array}$ & Leaf no. & $\begin{array}{l}\text { Actual LA } \\
\left(\mathrm{cm}^{2}\right)\end{array}$ & $\begin{array}{c}\text { TCA } \\
\left(\mathrm{mm}^{2}\right)\end{array}$ & $\begin{array}{c}\text { Plant dry } \\
\text { wt } \\
\text { (g) }\end{array}$ & $\begin{array}{c}\text { Avg SLD } \\
\left(\mathrm{mg} \cdot \mathrm{cm}^{-2}\right)\end{array}$ \\
\hline \multicolumn{7}{|c|}{ LAR between lateral veins } \\
\hline 0 & 110 & 42 & 2229 & 152 & 190 & 0.262 \\
\hline 10 & 96 & 39 & 1910 & 119 & 175 & 0.297 \\
\hline 20 & 93 & 40 & 1460 & 104 & 161 & 0.317 \\
\hline 30 & 74 & 31 & 1068 & 78 & 119 & 0.387 \\
\hline \multicolumn{7}{|c|}{ LAR across lateral veins } \\
\hline 0 & 112 & 42 & 2281 & 140 & 203 & 0.255 \\
\hline 10 & 90 & 38 & 1715 & 103 & 173 & 0.304 \\
\hline 20 & 86 & 36 & 1457 & 102 & 166 & 0.344 \\
\hline 30 & 85 & 35 & 1204 & 90 & 128 & 0.370 \\
\hline Position & NS & NS & NS & . NS & NS & NS \\
\hline Level & $* * *$ & $* *$ & $* * *$ & $* * *$ & $* * *$ & $* * *$ \\
\hline Position $\times$ level & NS & NS & NS & NS & NS & NS \\
\hline
\end{tabular}

${ }^{2}$ Values are the means of eight plant replicates.

NS, $*, * * * * *$ Nonsignificant or significant at $P=0.1,0.05$, or 0.01 , respectively. Position and level identify main and split-plot effects, respectively.

removal of up to $20 \%$ of the LA of individual leaves did not significantly reduce A on a whole-leaf basis, but removal of $30 \%$ of the LA did (Fig. 2B). Apparently, 30\% LAR exceeds the compensatory capacity of the individual cherry leaf. This apparent threshold, where $20 \%$ LAR did not significantly reduce A, has also been observed in other crops (Boucher et al., 1987; Flore and Irwin, 1983; Poston et al., 1976; Proctor et al., 1982).

Photosynthetic compensation following up to $20 \%$ LAR between veins (Fig. $3 \mathrm{~A}$ and $\mathrm{C}$, Table 1) could possibly be the result of both an enhanced rubisco activity and RuBP regeneration capacity. von Caemmerer and Farquhar (1984) observed similar changes in rubisco activity and capacity of RuBP regeneration following defoliation in bean. Wareing et al. (1968) observed increased rubisco activity in partially defoliated bean leaves and suggested that defoliation increased the demand of the remaining LA for photosynthates. They also noted that noninjured leaves were not operating at their maximum photosynthetic potential; this appears to be the case for noninjured sour cherry leaves as well. Since $1_{\mathrm{g}}$ was only minimally affected by LAR level (Table 1), the major limitation to A following partial defoliation in sour cherry appears to be the mesophyll.

The increase in $R_{1}$ as LAR between and across veins increased (Table 2) should have increased the competition between carboxylation/oxygenation of rubisco for RuBP, thus affecting A most at saturating $C_{i}$, when RuBP regeneration capacity should have been limiting (Farquhar and Sharkey, 1982). Hodgkinson (1974) also observed higher R, values in partially defoliated lucerne (Medicago sativa L.) plants. $\mathrm{A}_{\max }$ at saturating $\mathrm{C}_{\mathrm{i}}$ was $52 \%$ or $27 \%$ higher than the control leaves when $10 \%$ or $20 \%$ of the leaf area was removed between veins, respectively (Table 1 ), yet $R_{1}$ was $85 \%$ or $155 \%$ higher in these leaves (Table 2). The dramatic increase in $\mathrm{R}$, associated with an increase in $\mathrm{A}_{\max }$ suggests that the RuBP regeneration capacity of leaves with up to $20 \%$.LAR between veins most likely was enhanced. Since $\mathrm{A}_{\max }$ was reduced following LAR across veins relative to the control, this reflects a diminished $\mathrm{CO}_{2}$ assimilatory capacity that cannot be overcome by increasing the $\mathrm{CO}_{2}$ supply. These data, in addition to $\mathrm{k}$ values (Table 1), indicate that photosynthetic compensation for LAR in sour cherry is most likely due to enhancement of both carboxylation efficiency and RuBP regeneration capacity.
Responses of A to PPF (Table 2) were measured to predict effects of defoliation on other gas exchange characteristics. Dark respiration was only minimally affected by LAR level in sour cherry and was not affected by virus infection of peach [Prunus persica (L.) Batsch] leaves (Smith and Neales, 1977) or leaf miner infestation of apple leaves (Proctor et al., 1982). The light compensation point was minimally affected by LAR level in sour cherry and not by virus infection in peach (Smith and Neales, 1977). Photochemical efficiency was significantly reduced in sour cherry leaves, especially when LA was removed across veins or when $30 \%$ of the LA was removed between veins. The lower $\phi$ values for LAR across veins or $30 \%$ LAR between veins indicate that light capture and electron transport processes underlying RuBP regeneration may be less efficient in these leaves. Proctor et al. (1982) and Smith and Neales (1977) did not observe significant "effects of leaf miner infestation or virus infection on $\phi$ of mature leaves, but the latter authors did observe a significant reduction in $\phi$ upon virus infection of young peach leaves. At saturating PPF, $A_{\max }$ was significantly reduced as LAR level across veins increased. Proctor et al. (1982) observed a similar relationship for leaf minerinfested apple leaves. This pronounced decline in A at saturating PPF indicates that RuBP regeneration capacity maybe limiting A since nonlimiting light energy is available.

LAR that exceeded the estimated threshold of $20 \%$ in sour cherry affected $\phi$ more than $\mathrm{k}$ (Tables 1 and 2 ). Leaf volume increased (as indicated by SLD), but LA did not change (Table 3 ). The actual reduction of leaf surface area for light trapping may have affected A more than the reduction in leaf volume affected carboxylation, especially since leaf volume increased over time. Satoh et al. (1977) and Hodgkinson (1974) have observed leaf thickening following partial defoliation. Mesophyll cell enlargement may have been due to the production of more photosynthetic "machinery" (e.g., proteins such as rubisco), since Satoh et al. (1977) observed a greater depth and more columnar stacking in the palisade and spongy mesophyll. Starch accumulation was less and A was higher in leaves of partially defoliated than nondefoliated mulberry plants (Satoh et al., 1977), presumably due to the increased sink demand of the remaining LA. However, Ramirez et al. (1988) suggested that, as defoliation increased in cucumber (Cucumis sativus L.), dry 
Weight (and possibly starch) accumulation acted as a feedback mechanism to inhibit A. Since leaf starch content was not determined in these experiments, one cannot rule out a feedback effect on $\mathrm{A}$ in noncompensating leaves.

Removal of $25 \%$ of the leaf area of tomato (Stacey, 1983) and cucumber plants (Ramirez et al., 1988) did not significantly affect yield or whole-plant dry matter accumulation. Removing $50 \%$ of the leaf area of potted apple trees reduced dry weight accumulation only 40\% (Maggs, 1964), suggesting that some kind of compensation must have occurred. Flore and Irwin (1983) did not observe a significant reduction in fresh weight or TCA of apple trees until $20 \%$ or more of the, leaf area of the whole plant was removed. In our experiments, the reduction of whole-plant dry weight from $10 \%$ to $20 \%$ LAR between or across veins was only $8 \%$ or $5 \%$, respectively, whereas the reduction of whole-plant dry weight from $20 \%$ to $30 \%$ LAR between or across veins was $32 \%$ or $26 \%$, respectively (Table 3 ). Although whole-plant dry weight accumulation was reduced following LAR in sour cherry, this disproportionately large decrease between $20 \%$ to $30 \%$ LAR would suggest that 30\% LAR exceeded the threshold LAR level, as was noted for the gas exchange study, and that compensation was occurring at the $20 \%$ LAR level. It is peculiar that $30 \%$ LAR between veins resulted in a slightly lower plant dry weight than the same level of LAR across veins. Based on the gas exchange data, we would not have predicted this outcome. In any event, this threshold for LAR was established for potted 1-year-old trees grown in the greenhouse. It represents a significant compensation ability for sour cherry, but the threshold may change with crop load and environment.

Ethylene evolution is usually stimulated by wounding. Ethylene production by tobacco (Nicotiana tabacum L.) leaves inoculated with tobacco mosaic virus increased over 8 days as local lesions developed (Nakagaki et al., 1970). Wound ethylene production of sour cherry leaves damaged by leaf-punching dropped off after 12 $\mathrm{h}$ and was essentially unchanged after $24 \mathrm{~h}$. Because the wounding event was instantaneous rather than prolonged, as might be expected during an infection, wounds probably healed rapidly and the wounding response was hastened. The wounding response was greater for IAR across than between veins, and wound ethylene evolution increased as LAR increased. LAR across lateral veins is probably more injurious to the leaf than leaf-punching through the lamina. Some plants suffer photosynthetic depression in response to ethylene (Taylor and Gunderson, 1986), while others, including apple (Dozier and Barden, 1971) and tomato (Bradford, 1983), do not. Although the effects of ethylene on gas exchange of sour cherry were not evaluated in this study, we do not believe that it significantly influenced A. Because wound ethylene evolution had essentially ceased after $24 \mathrm{~h}$, the wounds to the leaves were probably healed by then. If ethylene had still been produced at inhibitory levels 7 days following LAR, then the compensation observed (Fig. IB) upon 20\% LAR across veins should not have occurred.

Defoliation can dramatically affect productivity of cultivated plants and should, therefore, be kept to a minimum. Studies such as ours aid in determining damage thresholds for a crop. Clearly, many plants can compensate for certain levels of damage or injury. By knowing what these levels are and how to measure them in the field, and by being able to predict responses (e.g., reduced productivity or winter hardiness), the grower may choose to treat or not treat the situation. In circumstances where prophylactic pest control is always used, knowledge of damage thresholds may reduce the frequency of pesticide applications and preserve populations of beneficial insects in the environment.

\section{Literature Cited}

Bassman, J., W. Myers, D. Dickmann, and L. Wilson. 1982. Effects of simulated insect damage on early growth of nusery-grown hybrid poplars in northern Wisconsin. Can. J. For. Res. 12:1-9.

Boucher, T. J., D.G. Pfeiffer, J.A. Barden, and J.M. Williams. 1987. Effects of simulated insect injury on net photosynthesis of potted grapevines. HortScience 22:927-928.

Bradford, K.J. 1983. Involvement of plant growth substances in the alteration of leaf gas exchange of flooded tomato plants. Plant Physiol. 73:480-483.

Briggs, J.B. and D.J. Avery. 1968. Effects of infestation with fruit tree red spider mite, Panonychus ulmi (Koch), on the growth and cropping of young fruit trees. Ann. Applied Biol. 61:269-276.

Childers, N. F., G.E. Marshall, and H.W. Brody. 1941. The effect of leafhopper injury on the rates of apparent photosynthesis and transpiration of 'Stayman Winesap' apple leaves. Proc. Amer. Soc. Hort. Sci. 38:165.

Dozier, W. A., Jr., and J.A. Barden. 1971. Net photosynthesis and respiration of apple leaves influenced by (2-chloroethyl) phosphoric acid. J. Amer. Soc. Hort. Sci. 96:789-790.

Ellis, M. A., D.C. Ferree, and D.E. Spring. 1981. Photosynthesis, transpiration, and carbohydrate content of apple leaves infected by Podosphaera leucotricha. Phytopathology 71:392-395.

Farquhar, G.D. and T.D. Sharkey. 1982. Stomatal conductance and photosynthesis. Annu. Rev. Plant Physiol. 33:317-345.

Flore, J.A. and C. Irwin. 1983. The influence of defoliation and leaf injury on leaf photosynthetic rate, diffusive resistance, and whole tree dry matter accumulation in apple. HortScience 18:72. (Abstr.)

Hodgkinson, K.C. 1974. Influence of partial defoliation on photosynthesis, photorespiration and transpiration by lucerne leaves of different ages. Austral. J. Plant Physiol. 1:561-578.

Hunt, R. 1980. Asymptotic functions, p. 121-146. In: Plant growth curves-The functional approach to plant growth analysis. University Park Press, Baltimore, Md.

Jones, H.G. 1985. Partitioning stomatal and nonstomatal limitations to photosynthesis. Plant, Cell \& Environ. 8:95-104.

Kappes, E.M. 1985. Carbohydrate production, balance, and transpiration in leaves, shoots and fruits of 'Montmorency' sour cherry. PhD Diss., Michigan State Univ., East Lansing. (Diss. Abstr. 8613300).

Layne, D.R. and J.A. Flore. 1991. Short- and long-term effects of source manipulation in sour cherry (Prunus cerasus L.). HortScience 26(6):132. (Abstr.)

Li, J. and J.T.A. Proctor. 1984. Simulated pest injury effects photosynthesis and transpiration of apple leaves. HortScience 13:815-817.

Lienk, S. E., P.J. Chapman, and O.F. Curtis, Jr. 1956. Responses of apple trees to mite infestations II. J. Econ. Entomol. 49:350-353.

Lownds, N.K. 1987. Interactions of surfactants with plant leaves: Induction of phytotoxicity and ethylene production in relation to surfactant chemistry. PhD Diss., Michigan State Univ., East Lansing. (Diss. Abstr. 87-14345).

Maggs, D.H. 1964. Growth-rates in relation to assimilate supply and demand. L Leaves and roots as limiting regions. J. Expt. Bet. 15:574583.

Mobley, K.N. and R.P. Marini. 1990. Gas exchange characteristics of apple and peach leaves infested by European red mite and twospotted spider mite. J. Amer. Soc. Hort. Sci. 115:757-761.

Moon, J.W. and J.A. Ftore. 1986. A BASIC computer program for calculation of photosynthesis, stomatal conductance, and related parameters in an open gas exchange system. Photosynthesis Res. 7269-279.

Nakagaki, Y., T. Hirai, and M.A. Stahmann. 1970. Ethylene production by detached leaves infected with tobacco mosaic virus. Virology 40:1-9.

Poston, F. L., L.P. Pedigo, R.B. Pearce, and R.B. Hammond. 1976. Effects of artificial and insect defoliation on soybean net photosynthesis. J. Econ. Entomol. 69:109-112.

Proctor, J. T. A., J.M. Bodnar, W.J. Blackburn, and R.L. Watson. 
1982. Analysis of the effects of the spotted tentiform leaf miner (Phyllonorycter blancardella) on the photosynthetic characteristics of apple leaves. Can. J. Bet. 60:2734-2740.

Ramirez, D. R., T.C. Wehner, and C.H. Miller. 1988. Source limitation by defoliation and its effects on dry matter production and yield in cucumber. HortScience 23:704-706.

Sams, C.E. and J.A. Flore. 1982. The influence of age, position. and environmental variables on net photosynthetic rate of sour cherry leaves. J. Amer. Soc. Hort. Sci. 107:339-344.

Satoh, M., P.E. Kriedemann, and B.R. Loveys. 1977. Changes in photosynthetic activity and related processes following decapitation in mulberry trees. Physiol. Plant. 41:203-210.

Shaw, M. and D.J. Samborski. 195.6. The physiology of host parasite relations. I. The accumulation of radioactive substances at infections of facultative and obligate parasites including tobacco mosaic virus. Can. J. Bet. 34:389-405.

Smith, P.R. and T.F. Neales. 1977. Analysis of effects of virus in- fection on the photosynthetic properties of peach leaves. Austral. J. Plant Physiol. 4:723-732.

Spotts, R.A. and D.C. Ferree. 1979. Photosynthesis, transpiration, and water potential of apple leaves infected by Venturia inaequalis. Phytopathology 69:717-719.

Stacey, D.L. 1983. The effect of artificial defoliation on the yield of tomato plants and its relevance to pest damage. J. Hort. Sci. 58117-120.

Taylor, G. E., Jr., and C.A. Gunderson. 1986. The response of foliar gas exchange to exogenously applied ethylene. Plant Physiol 82653657.

von Caemmerer, S. and G.D. Farquhar. 1984. Effects of partial defoliation, changes of irradiance during growth, short-term water stress and growth at enhanced $\mathrm{p}\left(\mathrm{CO}_{2}\right)$ on the photosynthetic capacity of leaves of Phaseolus vulgaris L. Planta 160:320-329.

Wareing, P. F., M.M. Khalifa, and K.J. Treharne. 1968. Rate-limiting processes in photosynthesis at saturating light intensities. Nature (London) 220:453457. 